\title{
Analysis and evaluation of the impact of stand age on the occurrence and metamorphosis of red heartwood
}

\author{
Marek Trenčiansky, \\ Martin Lieskovský, \\ Ján Merganič, \\ Rastislav Šulek
}

\begin{abstract}
The red heartwood of beech is responsible for decreasing the market value of the most important deciduous tree species of central Europe. The aims of this study were: (i) to verify the hypothesis that stand age affects the occurrence and metamorphosis of red heartwood in beech; and (ii) to quantify the economic loss due the sale price reduction of timber affected by red heartwood. Seven even-aged beech stands of different age $(87,100,105,110,115,132$, and 145 years) were selected in Slovakia, and 213 trees were cut into 961 pieces of assortments which were evaluated for the presence, form and extension of red heartwood. The economic loss caused by red heartwood was determined as the difference in price between the actual and the potential quality grades of assortments. The results confirmed that stand age significantly influence the occurrence, development, and metamorphosis of red heartwood. The average loss in timber sale price caused by red heartwood varied between 0.76 and $28.04 € \mathrm{~m}^{-3}$, depending on age and form of red heartwood, with more severe losses in stands older than 110 years. To reduce the incidence of beech red heartwood in Central Europe, a reduction of the rotation period should be considered, as well as the adoption of suitable silvicultural practices in aged beech stands.
\end{abstract}

Keywords: Red Heartwood, Economics of Beech, Timber Quality, Timber Prices ally occurring in beech trunks at a cambial age of 40 years (Račko \& Cunderlík 2011). Red heartwood formation is affected by various factors, which cause the death of parenchyma cells (Chovanec 1974) and allow the formation of tylosis. One of the most important factors is the penetration of air into the mature zone of the stem through the discontinuities occurring on trunk surface (knots, injuries, defects, etc.). The risk of red heartwood formation increases with increasing age and diameter at breast height of trees (Knoke 2003, Schmidt et al. 2011), although an effect of stand site conditions has also been reported (Gomez \& Bock 2010).

The rotation period of beech stands in Central Europe mostly ranges from 110 to 140 years. However, in some countries (e.g., Austria, Switzerland, Hungary), it has been occasionally shortened to $80-100$ years for reducing the unfavorable consequences of red heartwood formation. Typi-
Technical University in Zvolen, T. G. Masaryka 24, SK 96053 Zvolen (Slovak Republic)

@ Marek Trenčiansky (trenciansky@tuzvo.sk)

Received: May 16, 2016 - Accepted: Feb 15, 2017

Citation: Trenčiansky M, Lieskovský M, Merganič J, Šulek R (2017). Analysis and evaluation of the impact of stand age on the occurrence and metamorphosis of red heartwood. iForest 10: 605-610. - doi: 10.3832/ifor2116-010 [online 2017-05-15]

Communicated by: Giacomo Goli cally, the value of a stand and the attainable timber assortments increases over the stand rotation time; however, the presence of red heartwood can lead to the opposite trend. Therefore, a compromise must be achieved by the proper management of beech stands and the determination of their appropriate harvesting age (Prka \& Krpan 2010). The risk of a decrease in timber quality due to the development of red heartwood could be reduced by earlier silvicultural interventions and shorter production times (Zell et al. 2004). Nonetheless, the actual influence of stand age on the occurrence and development of red heartwood has to be confirmed and verified in real cases.

Several studies have focused on the economic loss caused by red heartwood (Seeling 1998, Richter 2001, Knoke 2002, Von Büren 2002). The economic loss has been estimated by value models (Von Büren 2002), via timber purchasers or processors (Seeling 1998), based on the results of forest inventory (Richter 2001), and by the application of beech harvesting strategies focused on the elimination of the unfavourable influences of red heartwood (Knoke 2002).

According to Sachsse (1991), red heartwood can be classified in several basic forms: classical, spattering, abnormal, and wound heartwood. In particular, spattering and abnormal red heartwood strongly devalues the timber and its assortments. Moreover, the presence of red heartwood can further devalue beech timber when it 


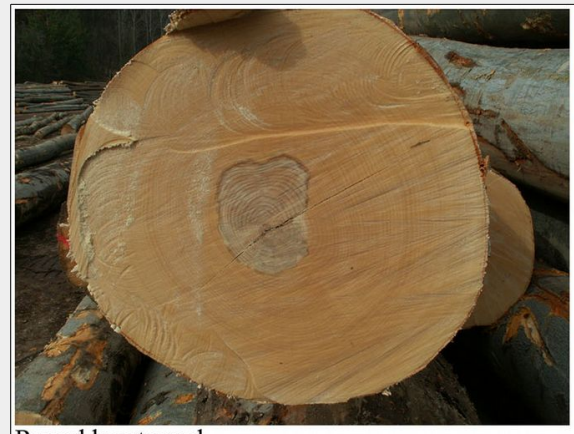

Round heartwood

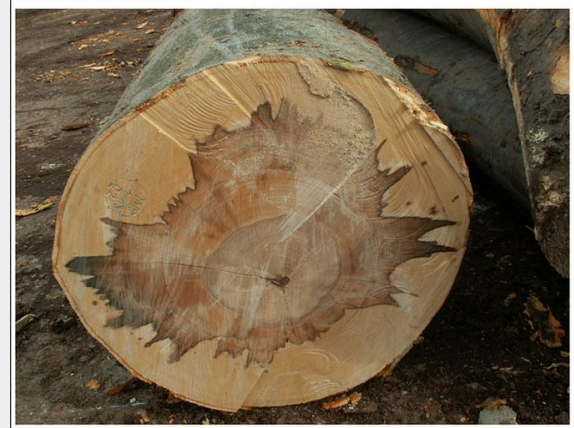

Spattering heartwood

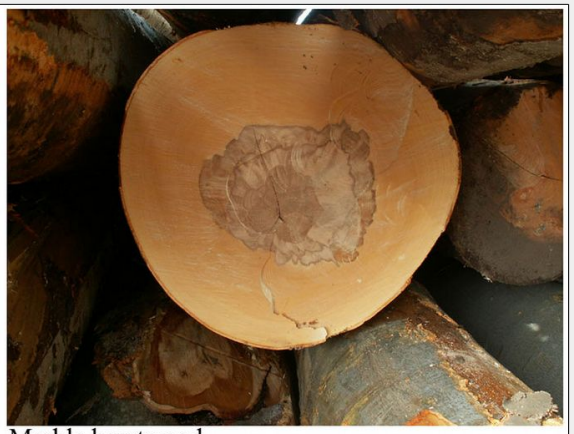

Marble heartwood

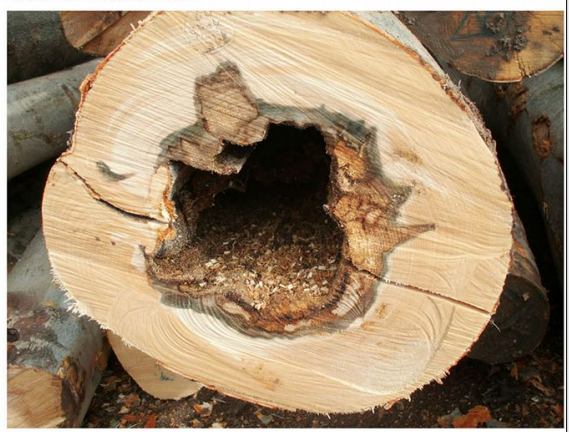

Rot heartwood

Fig. 1 - Different forms of red heartwood in beech timber.

is attacked by wood-destroying fungi, which can cause the formation of heart rots.

The aim of this study is to analyse the influence of stand age on the occurrence and metamorphosis of red heartwood, and to quantify the loss in average price of beech timber assortments as a function of age and the presence of various forms of red heartwood. To this purpose, we tested the following hypotheses: (i) the age of the stand significantly affects the occurrence and metamorphosis of red heartwood in beech trunks; (ii) the age of the stand and the form of heartwood significantly affects the market price of beech wood assortments.

\section{Material and methods}

The methodology followed in this studycan be divided into three stages:
- selection of stands, tree harvesting, and identification and measurement of heartwood;

- cross-cutting and sorting of assortments, and identification and measurement of heartwood of individual assortments;

- processing of data, analysis of the age of the heartwood occurrence, analysis of timber sale prices, and calculation of loss.

\section{Stand selection, tree harvesting, and} heartwood classification

The analysis of seven beech stands at the University Forestry Enterprise of the Technical University in Zvolen (Slovak Republic) was carried out over the years 2002-2014. The basic source of data on forest stands was the forest management plan of the University Forest Enterprise. Data included seven stands aged $87,100,105,110,115,132$, and 145 years. Due to the past clear-cutting
Fig. 2 - Measurement of red heartwood as the diameter of the circle of the contaminated area (a) at the thicker end of assortments.

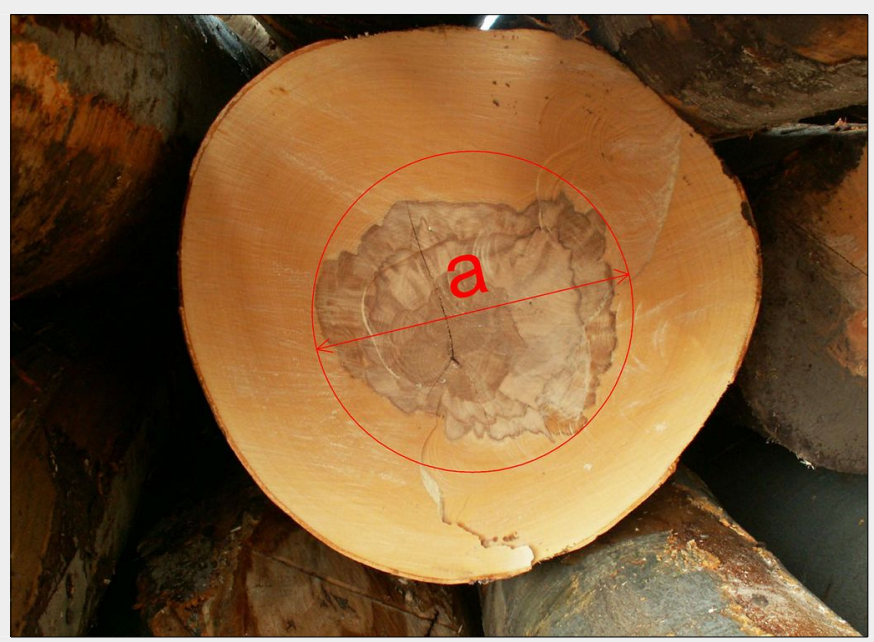

management of these forest stands, they might be considered to be even-aged.

Stands sharing similar site conditions were included the analysis. All the stands were located in the region of "Kremnické vrchy" (the Kremnica Mountains - 48 $38^{\circ}$ $06.99^{\prime \prime} \mathrm{N}, 19^{\circ} 02^{\prime} 38.69^{\prime \prime} \mathrm{E}$ ). The average annual precipitations in the area range from 650 to $700 \mathrm{~mm}$. Pyroxenic and amphibolic-pyroxenic andesite is the common geological bedrock, while the soil type is a brown forest soil.

All the selected stands were growing at altitude of 400 to $500 \mathrm{~m}$ a.s.l. with slopes of $30 \%$ to $40 \%$, but with different aspects: east for three stands $(87,105,145$ years of age), west for two stands (aged 100 and 115 years), and north-east for the remaining two stands (110 and 132 years). For all stands, the share of beech was approximately $80 \%$ to $100 \%$ of the species, and its absolute site index (stand height at age of 100 years) was between 26 and $28 \mathrm{~m}$.

In each stand, 10 to 77 representative trees were marked before being harvested, and height, diameter at breast height, and volume were measured for each tree. After felling, the red heartwood was identified and classified in one of the following forms: round, marble, spattering, and rot heartwood (Fig. 1). The size of heartwood was measured according to technical standards (STN-EN-1310 2000) as the diameter of the circle surrounding the contaminated area ( $a$ - Fig. 2) and expressed as the percentage of thickness measured at the thicker end of assortments.

Overall, some 213 trees were cut into 961 pieces of assortments, with a total volume of $510.83 \mathrm{~m}^{3}$.

\section{Sorting of assortments and quality} grade assignment

The sorting of the felled timber was carried out at a hauling location, in accordance with the technical standards of the Slovak Republic (STN-480056 2007). Assortments were categorized into six grades based on quality, from the first grade (the highest quality used for the production of veneers and musical instruments) to the sixth grade (the lowest quality used for fuelwood). Tab. 1 displays the quality grades and restrictions in relation to the forms of red heartwood, according to the Slovak (STN-480056 2007) and European (STN-EN-1316-1 2013) technical standards. In general, the tolerance for red heartwood decreases with increasing the quality grade of assortments.

Assortments were classed based on their "actual" and "potential" quality grades, the latter being calculated as if the assortment contained no red heartwood while keeping all other quality criteria (knots, cracks, sweep, spiral grain, etc.). The average loss caused by the presence of red heartwood was determined as the difference of price between the actual and the potential quality grades for a given assortment. The classification of timber assort- 
Tab. 1 - The red heartwood forms and quality grades according to STN-480056 (2007) and STN-EN-1316-1 (2013).

\begin{tabular}{|c|c|c|c|c|}
\hline \multicolumn{3}{|c|}{ STN-480056 } & \multicolumn{2}{|c|}{ STN-EN-1316-1 } \\
\hline $\begin{array}{l}\text { Quality } \\
\text { grade }\end{array}$ & Use & Description & $\begin{array}{l}\text { Quality } \\
\text { grade }\end{array}$ & Description \\
\hline I. & $\begin{array}{l}\text { veneer logs, logs for } \\
\text { musical instruments }\end{array}$ & $\begin{array}{l}\text { to } 20 \% \text { of log butt end area rot heartwood not } \\
\text { allowed }\end{array}$ & $F-A$ & $\begin{array}{l}<20 \% \text { log butt end area, spattering not } \\
\text { allowed, rot heartwood not allowed }\end{array}$ \\
\hline II. & veneer logs & $\begin{array}{l}\text { round and spattering to } 1 / 3 \text { of log butt end area } \\
\text { rot heartwood allowed up to } 8 \mathrm{~cm} \text { from the pith }\end{array}$ & \multirow{2}{*}{ F-B } & \multirow{2}{*}{$\begin{array}{l}<30 \% \text { log butt end area, spattering in } \% \\
\text { thickness }<10 \% \text {, rot heartwood }<15 \% \text { log } \\
\text { butt end area }\end{array}$} \\
\hline III.A & saw logs & $\begin{array}{l}\text { to } 1 / 3 \text { of log butt end area, spattering not } \\
\text { allowed rot heartwood not allowed }\end{array}$ & & \\
\hline III.B & saw logs & $\begin{array}{l}\text { to } 1 / 2 \text { of log butt end area, spattering to } 1 / 3 \text { of } \\
\text { log butt end area rot heartwood not allowed }\end{array}$ & $\mathrm{F}-\mathrm{C}$ & $\begin{array}{l}\text { round is allowed spattering to } 40 \% \text { of log } \\
\text { butt end area rot heartwood }<25 \% \text { log butt } \\
\text { end area }\end{array}$ \\
\hline V.-VI. & $\begin{array}{l}\text { V - pulpwood } \\
\text { VI - fuelwood }\end{array}$ & allowed & $F-D$ & allowed \\
\hline
\end{tabular}

ments into actual quality grades was done by the operational staff of the University Forest Enterprise, while all measurements of red heartwood and the classification of timber assortments to their potential quality grade was carried out by a single person (MT) not belonging to the operational staff.

\section{Statistical analysis}

All data of the analyzed trees (diameter at breast height, height, volume, size and form of red heartwood) and of the timber assortments (length, thickness, size and form of red heartwood, real quality grade and its price, potential quality grade and its price) were organized in a single dataset to be processed. First, we analyzed the effect of stand age and tree size on the occurrence of red heartwood and its metamorphosed forms from healthy (round, marble heartwood) to unhealthy states (spattering heartwood or rot heartwood). Differences in the occurrence of red heartwood forms among stands of different age were tested using contingency tables and $\chi^{2}$ test with $\alpha=0.05$. Pearson's contingency correlation coefficients and Cramer's V coefficients were also calculated.

Secondly, we quantified the losses in the average timber sale price caused by the different forms of red heartwood in relation to stand age. The sale price of each assortment was calculated based on its diameter and quality grade, using the price list of the state enterprise Forests of the Slovak Republic (SR-Forests 2015). As beech assortment prices have recorded a stagnation since the global crisis of 2008 (Gejdoš \& Danihelová 2015), we limited our analysis to the data collected in the period 20082015.

The average loss in sale price for $1 \mathrm{~m}^{3}$ of timber $(\mathrm{L})$ was quantified as the difference between the actual and the potential price attainable for each assortment using the same price list. Differences in the average loss among either stand ages or red heartwood forms were separately tested using the non-parametric Kruskal-Wallis one-way analysis of variance by ranks (due to departure from normality of the data). Pairwise multiple comparison of mean ranks were done by applying the post-hoc Dunn's and Conover's tests. All these analyses were carried out using the PMCMR package in the software R (Pohlert 2014).

\section{Results and discussion}

\section{Age effect on red heartwood occurrence}

The incidence of different forms of red heartwood at the different stand ages are presented in Tab. 2. In younger stands, aged less than 100 years, trees without red heartwood were fairly common, while their proportion decreases as the stand age increases. In the stands aged over 130 years, almost all trees were damaged by red heartwood. The occurrence of healthy heartwood forms (round, marble) reached a peak at the age of 115 . In younger stands (87 to 110 years), the proportion of trees with healthy heartwood ranged from 15 to $30 \%$. Spattering heartwood was the dominant form in stands aged over 130 years. The presence of rot heartwood tended to increase with stand age, from $5 \%$ in 87 -year old stands to $41 \%$ in 145 -year old stands.

Red heartwood in beech wood changes with time from healthy (round, marble heartwood) to unhealthy forms (spattering and rot heartwood). The incidence of the various forms of red heartwood (healthy, unhealthy, no heartwood) observed in this study at different stand ages is shown in Fig. 3. It is worth to notice, however, that red heartwood may also change its size and form along the stem of individual

Tab. 2 - Incidence of red heartwood at different stand age. (N): Number of trees; (\%): proportion of the total number of trees.

\begin{tabular}{|c|c|c|c|c|c|c|c|c|c|c|c|c|c|c|}
\hline \multirow{3}{*}{$\begin{array}{l}\text { Red heartwood } \\
\text { form }\end{array}$} & \multicolumn{14}{|c|}{ Stand age (years) } \\
\hline & \multicolumn{2}{|c|}{87} & \multicolumn{2}{|c|}{100} & \multicolumn{2}{|c|}{105} & \multicolumn{2}{|c|}{110} & \multicolumn{2}{|c|}{115} & \multicolumn{2}{|c|}{132} & \multicolumn{2}{|c|}{145} \\
\hline & $\mathbf{N}$ & $\%$ & $\mathrm{~N}$ & $\%$ & $N$ & $\%$ & $N$ & $\%$ & $\mathrm{~N}$ & $\%$ & $\mathbf{N}$ & $\%$ & $N$ & $\%$ \\
\hline None & 10 & 50.0 & 6 & 60.0 & 34 & 44.2 & 6 & 42.9 & 2 & 3.8 & 1 & 4.5 & 0 & 0.0 \\
\hline Healthy round & 3 & 15.0 & 0 & 0.0 & 8 & 10.4 & 1 & 7.1 & 19 & 35.8 & 1 & 4.5 & 0 & 0.0 \\
\hline Healthy marble & 1 & 5.0 & 3 & 30.0 & 4 & 5.2 & 3 & 21.4 & 11 & 20.8 & 4 & 18.2 & 0 & 0.0 \\
\hline Spattering & 5 & 25.0 & 0 & 0.0 & 22 & 28.6 & 2 & 14.3 & 9 & 17.0 & 9 & 40.9 & 10 & 58.8 \\
\hline Rot heartwood & 1 & 5.0 & 1 & 10.0 & 9 & 11.7 & 2 & 14.3 & 12 & 22.6 & 7 & 31.8 & 7 & 41.2 \\
\hline Total & 20 & 100 & 10 & 100 & 77 & 100 & 14 & 100 & 53 & 100 & 22 & 100 & 17 & 100 \\
\hline
\end{tabular}

trees. Indeed, heartwood may change from unhealthy to healthy forms moving upwards along the trunk. However, the opposite trend may also occur, e.g., in the case of tree-top wounding.

The variation in the proportion of the different forms of red heartwood with tree age was tested by contingency analysis (Tab. 3), where data were grouped in the following classes: (i) no heartwood; (ii) healthy heartwood (round, marble heartwood); (iii) and unhealthy heartwood (spattering and rot heartwood). Significant differences in the abundance of the different forms were found among different stand ages $\left(X^{2}=82.25 ; \mathrm{df}=12 ; \mathrm{p}<0.01\right)$. Thus, age could be considered a significant factor affecting the occurrence and the metamorphosis of red heartwood in beech stands, confirming the evidences previously reported in the literature (Sachsse 1991, Knoke 2003, Zell et al. 2004, Prka \& Krpan 2010, Schmidt et al. 2011).

\section{Quantification of loss in average sale prices}

To assess the economic loss caused by the impact of red heartwood in beech, we calculated the average sale price $\left(\epsilon \mathrm{m}^{-3}\right)$ of timber assortments obtained by cross-cutting of individual trees, according to their quality grade and age. As expected, the most valuable assortments $\left(1^{\text {st }}\right.$ and $2^{\text {nd }}$ quality grade) were obtained from younger stands (aged 87 to 105 years) that were not damaged by unhealthy forms of red heartwood. Younger stands also attained the 
Fig. 3 - Occurrence of red heartwood by form and stand age in the studied beech stands.

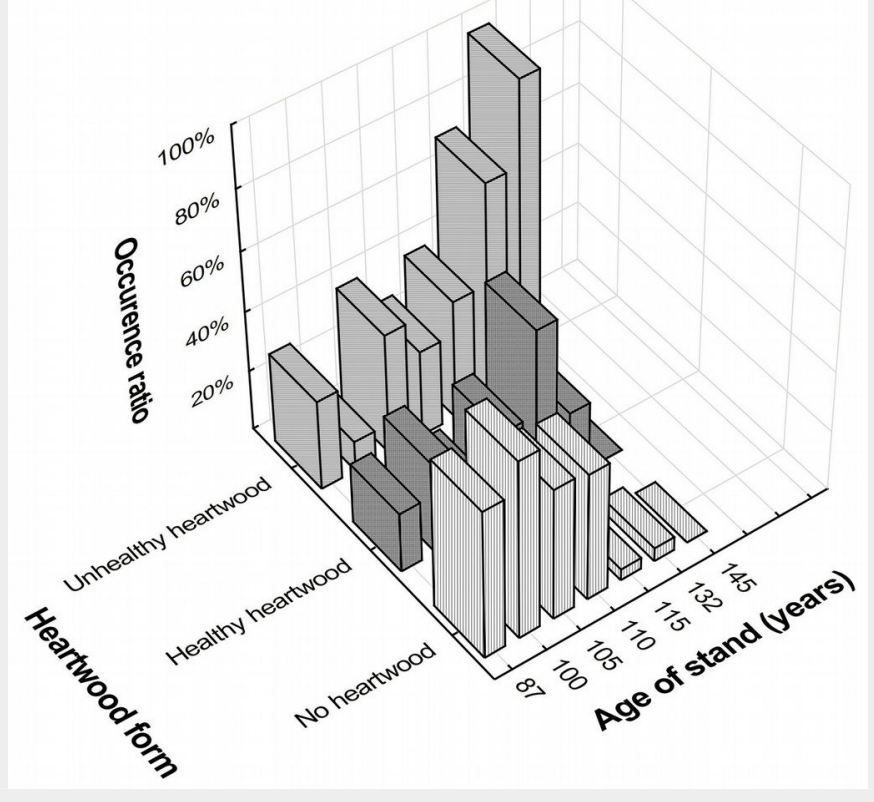

Tab. 3 - Incidence of healthy and unhealthy forms of red heartwood in beech according to stand age. Differences among different stand ages were significant $\left(\chi^{2}=82.25\right.$; $\mathrm{p}<0.01$; Pearson's coefficient $=0.53$; Cramer's V coefficient $=0.44$ ).

\begin{tabular}{cccc}
\hline $\begin{array}{c}\text { Stand } \\
\text { age }\end{array}$ & $\begin{array}{c}\text { No } \\
\text { heartwood }\end{array}$ & $\begin{array}{c}\text { Healthy } \\
\text { heartwood }\end{array}$ & $\begin{array}{c}\text { Unhealthy } \\
\text { heartwood }\end{array}$ \\
\hline 87 & 10 & 4 & 6 \\
100 & 6 & 3 & 1 \\
105 & 34 & 12 & 31 \\
110 & 6 & 4 & 4 \\
115 & 2 & 30 & 21 \\
132 & 1 & 5 & 16 \\
145 & 0 & 0 & 17 \\
\hline
\end{tabular}

highest average sales prices ( 57.41 to 65.84 $€ \mathrm{~m}^{-3}$ ). For older stands (aged 110 to 145 years), where healthy (115 years) and unhealthy (132, 145 years) forms of red heartwood were more abundant, we calculated a decrease in the average sale price by approximately 8 to $17 € \mathrm{~m}^{-3}$, as compared with younger stands. The difference between the highest and the lowest average sale price of assortments from older stands was only $1.58 € \mathrm{~m}^{-3}$. However, the decreas-

ing trend of average sale price was not statistically significant, despite the higher occurrence of unhealthy forms of red heartwood in older stands (110 to 145 year-old). This was caused by the increase in the diameter of assortments, which also involved an increase in sale prices. Therefore, we can conclude that the economic loss due to red heartwood is partly counterbalanced by the higher revenues from selling larger-sized timber assortments.

Fig. 4 - Relationship between stand age and the loss of average sale prices $\left(€ \mathrm{~m}^{-3}\right)$ of beach timber due to red heartwood. Error bars represent the $95 \%$ confidence intervals of the mean.

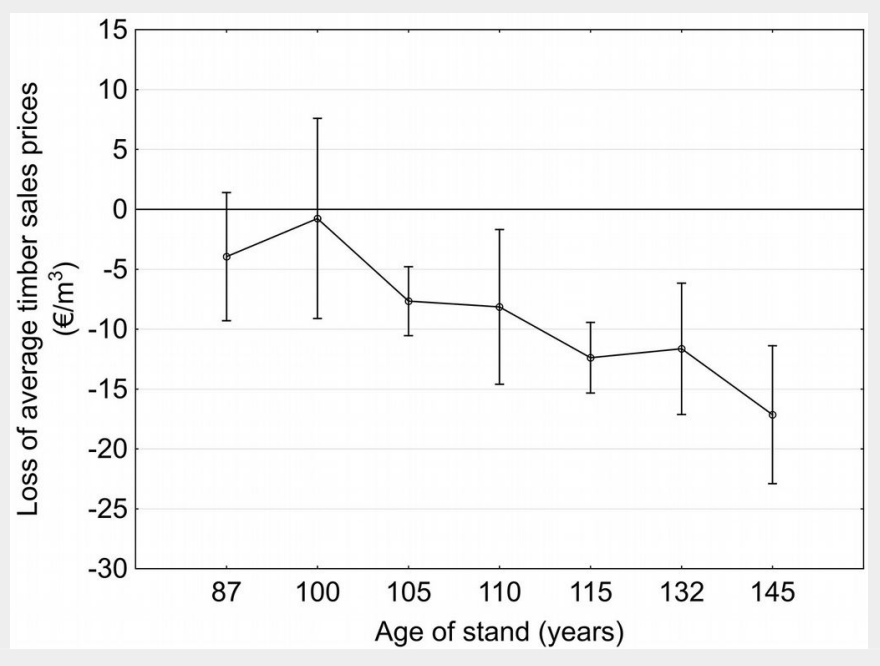

The revenues from the sale of assortments is affected by their classification to the different quality grades, their thickness and volume. The thickest assortments with the highest volume originate from the bottom parts of trees where the occurrence of unhealthy red heartwood is highest. Thus, the occurrence of unhealthy forms of heartwood may cause the most valuable assortments to be sold as pulpwood or even fuelwood. The prices per cubic meter of the top-quality assortments are 6.5 times higher than those of pulpwood. The average prices of beech sawlogs in the Slovak Republic and the Czech republic are 1.5 times higher than those of pulpwood, while in Austria it is more than 2 times higher (Suchomel et al. 2012, Gejdoš \& Suchomel 2016). As a consequence, the occurrence of unhealthy forms of heartwood may cause significant losses of revenues from the sale of beech timber assortments.

\section{The influence of stand age}

Fig. 4 shows the average loss in sale prices of beech timber at increasing stand age. The average timber sale prices due to red heartwood decreased as the stand age increased. Differences in sale prices were statistically significant after Kruskal-Wallis test $(p<0.01)$. This confirmed the hypothesis that stand age is inversely associated with the average sale prices of timber $\left(\chi^{2}=\right.$ 53.76, $\mathrm{df}=7, \mathrm{p}<0.01$ ).

The lowest average loss in sales price $\left(0.76 € \mathrm{~m}^{-3}\right)$ was found for the 100-year-old stand, while the highest loss $\left(17.14 € \mathrm{~m}^{-3}\right)$ was observed for the 145-year-old stand. The total average loss accounted for $9.68 €$ $\mathrm{m}^{-3}$. Von Büren (2002) studied the economic importance of beech red heartwood in Switzerland and found an average loss of $18.3 \mathrm{CHF} \mathrm{m}^{-3}\left(12.5 € \mathrm{~m}^{-3}\right.$, at the exchange rate of 2002). Depending on the region, the loss in timber value ranged from 10 to 22.8 CHF m${ }^{-3}$ (6.83 to $\left.15.57 € \mathrm{~m}^{-3}\right)$. In the region of Nordrhein Westfalen (Germany), Richter (2001) calculated a difference of 44 to $95 €$ $\mathrm{m}^{-3}$ between the actual and the potential price (given no heartwood) of the highest quality $A$ and $B$ grades (according to the European standards), with an average annual loss of 5 millions $€$ over a sold timber volume of 152 thousands $\mathrm{m}^{3}$. In the region of Niedersachsen (Germany), the estimated loss due to red heartwood was $6.5 \%$ of the revenue of beech wood sales based on the analysis of total annual harvesting (60,000 $\mathrm{m}^{3}$ - Seeling 1998). By applying a strategy of "quality conservation" based on the occurrence and dynamics of red heartwood, the net annual revenue from timber production ( $€ \mathrm{ha}^{-1}$ year $\left.{ }^{-1}\right)$ could be increased by $15 \%$ (Knoke 2002). Campu (2010) found that the downgrading of beech wood in Romania due to the presence of red heartwood could lead to a 40$50 \%$ decrease in the total revenue, irrespective of the sorting system applied.

Our findings indicated that the average loss in the sale price of wood due to red 
heartwood increased with age, especially in stands older than 110 years. To identify a threshold in the analyzed range of stand age, we applied the Dunn's and Conover's post-hoc tests to the average loss in sale prices, finding two distinct groups of stands. The first group included stands aged $87,100,105$, and 110 years, while the second included the stands aged 115, 132, and 145 years. Based on these results, we may argue that loss of sale revenues due to red heartwood was higher in the case of older forest stands as compared with the younger ones, and that the age threshold is between 110 and 115 years.

\section{The influence of red heartwood forms}

Significant differences in the average loss of sale prices were found among timber assortments affected by different heartwood forms $\left(X^{2}=279.9, d f=4, p<0.01\right)$. The decrease in average sale price was mainly due to the presence of unhealthy forms of heartwood. On average, the loss in price when healthy round heartwood was present was $6.95 € \mathrm{~m}^{-3}$, it was $13.97 € \mathrm{~m}^{-3}$ in the case of healthy marble heartwood, $16.64 €$ $\mathrm{m}^{-3}$ for unhealthy spattering heartwood, and $28.04 € \mathrm{~m}^{3}$ in the case of rot heartwood. Fig. 5 illustrates how the different forms of red heartwood affect the average loss in sale prices of beech wood. By grouping red heartwood in healthy and unhealthy forms, the difference in loss became even more remarkable ( 5.38 vs. 20.43 $€ \mathrm{~m}^{-3}$, respectively).

Our results confirmed that stand age significantly affects the occurrence and metamorphosis of beech red heartwood, and that the form of heartwood significantly affects the market price of beech timber assortments as well. Increased age and diameter are the two most important factors affecting the incidence of red heartwood (Knoke 2003). Previous studies correlated the formation and size of heartwood with trunk diameter (Rácz et al. 1961, Becker et al. 1989). Knoke \& Schulz Wenderoth (2001) found that the relative size of red heartwood increased by $0.7 \%$ as tree diameter at breast height increased by 1 $\mathrm{cm}$. However, the formation of heartwood is influenced not only by age or trunk diameter, but also by factors allowing the penetration of air into heartwood (Krempl \& Mark 1962). Injuries in the central root system are quite often the cause of spattering heartwood (Rieder 1997). Contrastingly, some authors suggested that the development of spattering heartwood is caused by fungi (Nečesany 1958).

The negative effects of red heartwood can be strongly attenuated by shortening the rotation period from the current range of 110-140 years (Halaj 1990) to 100-110 years. On the other hand, a shorter rotation period reduces the advantages of the volume increment of large-sized trees. Voss \& Brandl (1991) found the highest revenue per $\mathrm{m}^{3}$ of beech wood for stands aged 101 to 120 years. Rácz et al. (1961) re-

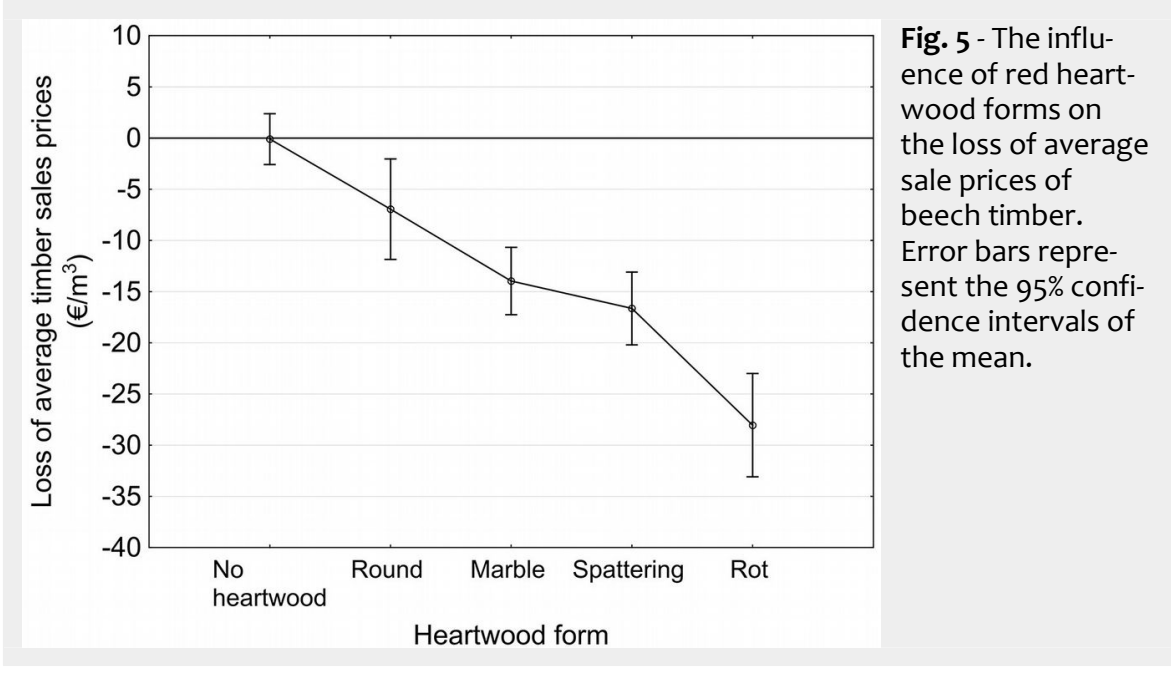

ported a high incidence of red heartwood also for stands with diameter at breast height of $50-60 \mathrm{~cm}$, and concluded that the production of high-dimension beech timber significantly increased the risk of growth of red heartwood. Zell et al. (2004) in a study aimed at the optimization of target diameter, found that smaller target diameters tended to have higher net present values.

To decrease the risk of red heartwood occurrence, the following measures shall be considered: (i) the selection of suitable location when establishing new stands (Pagan 1996); (ii) the employment of suitable silviculture practices (Assmann 1950, Gadow 1989, Saniga \& Bruchánik 2009); (iii) the identification of trees potentially invaded by red heartwood; and (iv) the determination of the optimum rotation period (Voss \& Brandl 1991) and/or the target diameter for the rotation period (Moog \& Karberg 1992, Zell et al. 2004). From the point of view of the wood-processing industry, healthy forms of red heartwood can be treated by steaming to reduce the colour differences between red and lightcoloured heartwood (Hansmann et al. 2009). Additional uses of beech timber affected by healthy forms of red heartwood include the production of attractive furniture, using different methods of sawmilling and dry killing (Verhoff \& Wurster 2002).

\section{Conclusion}

The results of the analysis on 213 beech trees from seven stands aged 87 to 145 years confirmed the hypothesis that stand age significantly affects the occurrence and metamorphosis of red heartwood. Heartwood develops following a predictable pattern, from no heartwood to healthy (round, marble) and then unhealthy forms of heartwood (spattering, rot heartwood).

The analysis of the average loss in sale price for 961 pieces of assortments revealed that higher prices were attained in younger stands $(87,100$, and 105 year-old) as compared with older stands (110, 115 , 132, and 145 year-old), whose average sales price was from 8 to $17 € \mathrm{~m}^{-3}$ lower than that of younger stands. The highest average sale price per $\mathrm{m}^{3}$ was attained at a stand age of 105 years.

The stand age and the form of heartwood significantly influenced the market value of beech wood assortments. Losses in average sale price due to age varied between 0.76 to $17.14 € \mathrm{~m}^{-3}$, with more severe losses in stands older than 110 years. Moreover, such loss increased with the presence of unhealthy forms of heartwood, raising from $5.38 € \mathrm{~m}^{-3}$ for healthy heartwood to $20.43 € \mathrm{~m}^{-3}$ for unhealthy forms of red heartwood in Slovak beech stands. Therefore, in order to reduce the incidence of red heartwood and the consequent economic loss, we recommend the rotation period to be shortened (wherever feasible) and suitable silvicultural practices to be adopted in aged beech stands of Central Europe.

\section{Acknowledgements}

This work was supported by Project VEGA no. 1/0688/16 "Economic and legal conditions of sustainable public access to forests".

\section{References}

Assmann E (1950). Grundflächen und Volumenzuwachs der Rotbuche bei verschiedenen Durchforstungsgraden [Basal areas and volume growth of beech at different thinning levels]. Forstwissenschaftliches Centralblatt 69 (5): 256-286. [in German] - doi: 10.1007/BF01822154 Becker D, Freist H, Ollgaard M (1989). Zielstarkennutzung und Buchenrotkern [Use of target trees and red heartwood of beech]. Forst und Holz 44 (1): 12-14. [in German]

Campu RV (2010). Research concerning the development of red heartwood and its influence on beech wood sorting. Bulletin of the Transilvania University of Brasov, Series II - Forestry, Wood Industry, Agricultural Food Engineering 3 (52): 11-16. [online] URL: http://webbut.unitbv. ro/bu2010/SeriesII/BULETINIIPDF/Forestry/Cam puRV.pdf

Chovanec D (1974). Možnosti zábrany vzniku bukového jadra [Possibilities of prevention of beech red heartwood]. Lesnícky Casopis 20 (4): 
339-354. [in Slovak]

SR-Forests (2015). Price list of the wood assortments. Forests of the Slovak Republic, State Enterprise, Website. [online] URL: http:// www.lesy.sk/showdoc.do?docid=2516

Gadow W (1989). Zielstärkennutzung und Buchenrotkern [Use of target trees and red heartwood of beech]. Forst und Holz 14 (14): 364. [in German]

Gejdoš M, Danihelová Z (2015). Valuation and timber market in the Slovak Republic. Procedia Economics and Finance 34: 697-703. - doi: 10.1016/S2212-5671(15)01688-3

Gejdoš M, Suchomel J (2016). Potential, prices and resources of raw wood assortments for the pulp and paper industry in central Europe. Key Engineering Materials 688: 210-217. - doi: 10.4028/www.scientific.net/KEM.688.210

Gfeller B (1998). Weisses und verkerntes Buchenholz in der Holzwirtschaft [White and red heartwood of beech in wood processing industry]. Schweizerische Zeitschrift für Forstwesen 149 (12): 943-953. [in German]

Gomez N, Bock J (2010). Comprendre et maîtriser le coeur rouge du hêtre [Understanding and controlling red heart in beech]. RenDezVous Techniques 27/28: 3-7. [in French]

Halaj J (1990). Rubná zrelost' drevín [Rotation maturity of tree species]. Lesnícke Štúdie 48, 117. [in Slovak]

Hansmann C, Stingl R, Teischinger A (2009). Inquiry in beech wood processing industry concerning red heartwood, Wood research 54 (3): 1-12. [online] URL: http://www.cabdirect.org/ cabdirect/abstract/20093311669

Knoke T (2002). Value of complete information on red heartwood formation in beech (Fagus sylvatica). Silva Fennica 36 (4): 841-851. [online] URL: http://m.metla.eu/silvafennica/full/sf36/sf 364841.pdf

Knoke T (2003). Predicting red heartwood formation in beech trees (Fagus sylvatica L.). Ecological Modelling 169 (2): 295-312. - doi: 10.1016/ S0304-3800(03)00276-X

Knoke T, Schulz Wenderoth S (2001). Ein Ansatz zur Beschreibung von Wahrscheinlichkeit und Ausmaß der Farbkernbildung bei Buche (Fagus sylvatica L.) [An approach to predict probability and extent of red coloured heartwood in beech (Fagus sylvatica L.)]. Forstwissenschaftliches Centralblatt 120 (3): 154-172. [in German] - doi: 10.1007/BF02796089

Krempl H, Mark E (1962). Untersuchungen über den Kern der Rotbuche [Investigations about the heartwood of beech]. Allgemeine Forstzeitung 73 (3): 186-191. [in German]

Mahler G, Höwecke B (1991). Verkernungserscheinungen bei der Buche in Baden-Württemberg in Abhängigkeit von Alter, Standort und Durchmesser [Occurrence of heartwood of beech in Baden-Württemberg depending on age, site and diameter]. Schweizerische Zeitschrift für Forstwesen 142 (5): 375-390. [in German]

Moog M, Karberg B (1992). Okonomische Gesichtspunkte zur Zielstärke von Kiefern und Buchen [Economic aspects of target dimension of pine and beech species]. Allgemeine Forst Zeitschrift fuer Waldwirtschaft und Umweltvorsorge 47 (2): 85-90. [in German]

Nečesany V (1958). Jádro Buku [Heartwood of beech]. SAV, Bratislava, Slovakia, pp. 256. [in Slovak]

Nečesany V (1969). Forstliche Aspekte bei der Entstehung des Falschkernes bei der Buche [Forestry aspects of the formation of false heart of Common beech]. Holz-Zentralblatt 95 (37): 563-564. [in German]

Pagan J (1996). Lesnícka Dendrológia [Forest dendrology]. Vydavatelstvo TU vo Zvolene, Slovakia, pp. 378. [in Slovak]

Pohlert T (2014). The pairwise multiple comparison of mean ranks package (PMCMR). $R$ package, Website. [online] URL: http://CRAN.R-pro ject.org/package=PMCMR

Prka M, Krpan APB (2010). Impact of tending measures on assortment structure of fellings in central Croatian beech stands. Acta Silvatica and Lignaria Hungarica 6 (2010): 171-182. [online] URL: http://publicatio.nyme.hu/1271/1/1 6_prka_krpan_p.pdf

Račko V, Cunderlík I (2011). Vplyv veku stromu na frekvenciu výskytu a velkost nepravého jadra buka (Fagus sylvatica L.) [Influence of tree age on frequency of occurrence and size of red heart in beech (Fagus sylvatica L.)]. Acta Facultatis Xylologiae Zvolen 53 (2): 5-14. [in Slovak]

Rácz J, Schulz H, Knigge W (1961). Untersuchungen über das Auftreten des Buchenkerns [Investigations about the occurrence of beech heartwood]. Der Forst- und Holzwirt 16 (19): 413-417. [in German]

Rathke KH (1996). Zu Rotkern bei Buche [About red heart of beech]. Allgemeine Forstzeitschrift 51 (23): 1312. [in German]

Richter J (2001). Buchenrotkern: Vermeiden oder Verwerten? [Beech red heart: avoid or use it?]. Forst und Holz 56 (2001): 662-664. [in German] Rieder A (1997). Einflussmöglichkeiten auf die Farbkernausbildung bei Buche [Possibilities of influencing the red heartwood formation in case of beech]. Österriechische Forstzeitung 108 (5): 34-36. [in German]

Sachsse H (1991). Kerntypen der Rotbuche [Heartwood types of common beech]. Forstarchiv 63 (4): 238-242. [in German]

Saniga M, Bruchánik R (2009). Prírode blízke obhospodarovanie lesa [Close nature forest stand management]. NLC Zvolen, Slovakia, pp. 104. [in Slovak]

Schmidt M, Nowack S, Riebeling R (2011). Methods and results of quantifying beech heart- wood in Hesse. Allgemeine Forst- und Jagdzeitung 182 (7/8): 146-159.

Seeling U (1998). Kerntypen im Holz - Konsequenzen für die Verwertung am Beispiel der Buche (Fagus sylvatica L.) [Heartwood types Consequences for timber utilisation in the case of beech (Fagus sylvatica L.)]. Schweizerische Zeitschrift für Forstwesen 149 (12): 991-1004. [in German]

STN-480056 (2007). Qualitative classification of hardwood round timber. Technical Standard of Slovakia, Slovak Office of Standards, Metrology and Testing, Bratislava, Slovakia, pp. 20.

STN-EN-1310 (2000). Round and sawn timber. Method of measurement of features. Technical Standard of Slovakia, Slovak Office of Standards, Metrology and Testing, Bratislava, Slovakia, pp. 24.

STN-EN-1316-1 (2013). Hardwood round timber. Qualitative classification. Part 1: Oak and beech Technical Standard of Slovakia, Slovak Office of Standards, Metrology and Testing, Bratislava, Slovakia, pp. 12.

Suchomel J, Gejdoš M, Ambrušová L (2012). Analysis of price changes of selected roundwood assortments in some Central Europe countries. Journal of Forest Science 58: 483-491. [online] URL: http://agriculturejournals.cz/publicFiles/78 446.pdf

Tarp P, Helles F, Holten-Andersen P, Bo Larsen J, Strange N (2000). Modelling near-natural silvicultural regimes for beech - an economic sensitivity analysis. Forest Ecology and Management 130 (1-3): 187-198. - doi: 10.1016/S0378-1127(99) 00190-5

Verhoff S, Wurster M (2002). Natürliche Merkmale der Buche wieder entdeckt [Natural features of beech rediscovered]. Holz-Zentralblatt 128 (115): 1374-1375. [in German]

Von Büren S (2002). Der Farbkern der Buche (Fagus sylvatica L.) in der Schweiz nördlich der Alpen [Red heartwood formation in beech: identification, occurrence and economic importance]. Schweizerische Zeitschrift für Forstwesen 86: 137. [in German]

Voss A, Brandl H (1991). Betriebswirtschaftliche Aspekte und Folgerungen zur Farbverkernung bei der Rotbuche in Baden-Württemberg [Economic aspects and implications for red heartwood of beech in Baden-Württemberg]. Mitteilungen der Forstliche Versuchs- und Forschungsanstalt Baden-Württemberg, Germany, Heft 158, Teil II, pp. 56. [in German]

Zell J, Hanewinkel M, Seeling U (2004). Financial optimisation of target diameter harvest of European beech (Fagus sylvatica) considering the risk of decrease of timber quality due to red heartwood, Forest Policy and Economics 6 (6): 579-593. - doi: 10.1016/\$1389-9341(03)0000 $7-8$ 